\title{
The influence of factor space on the value of discount rate in the assessment of investment projects
}

\author{
Yuliya Anoshina ${ }^{1, *}$, Valery Gusev ${ }^{1}$, Svetlana Suchkova ${ }^{2}$, Roman Gorshkov ${ }^{3}$ and Elena \\ Smorodina $^{4}$ \\ ${ }^{1}$ Moscow state University of technology and management. K. G. Razumovsky, Zemlyanoy Val street, \\ 73, Moscow, 109004, Russia \\ ${ }^{2}$ Gzhel State University, Moscow region, Ramensky district. p. Elektroizolyator, 67, 140155, Russia \\ ${ }^{3}$ Moscow State University of Civil Engineering, 129337, Yaroslavskoye shosse, 26, Moscow, Russia \\ ${ }^{4}$ Voronezh State Technical University, Moscow Avenue, 14, 394026, Voronezh, Russia
}

\begin{abstract}
The purpose of the paper is to identify factor space influencing on the value of discount rate in the assessment of effectiveness of investment and construction projects. As a result of investigation, a general classification of investment and construction risks was drawn up, depending on influence of external and internal environment of the enterprise. The factor space, which is used for initial data of separate investment and construction projects, was identified. A general algorithm of risk assessment of investment and construction project is developed, taking into account the reasoned justification of the method used for discount rate calculation, with the possible application of the variable discount rate at different stages of project's life cycle.
\end{abstract}

\section{Introduction}

One of the most important and difficult tasks that needs to be addressed in the process of performing works on justification and assessment of investment projects, is the task of discount rate definition (efficiency standard). The correct choice of discount rate significantly affects the accuracy of cost-effectiveness indicators of the estimated investment project. This is due to the high sensitivity of results of calculations from the value of the discount rate. That comes with the need for the reasoned justification of the method used for determination of discount rate and the values of parameters used. As well as performing its alternative calculations for all project participants, with the possible application of a variable discount rate for different steps of calculation [1].

Investors take the decision about project implementation on the basis of assessment of efficiency of investment and construction project, the result of which is significantly affected by accepted discount rate depending on the calculation method. In this work the preference is given to the cumulative build-up method, which includes risk assessments

\footnotetext{
${ }^{*}$ Corresponding author: jfano@mail.ru
} 
related to realization of investment and construction project. The choice of the cumulative method is justified by the simplicity of calculation and the greatest clearness of the influence of discount rate value on external project environment $[2,3]$.

As an economic category, risk is an event which might happen or not. From the financial management point of view, risk is a possibility of an unfavorable outcome which may consist in disrupting of deadlines of building of the facility, non-receipt of covered by project income or receiving the losses. In view of this, the natural reaction of investor to the presence of risk is the effort to compensate for it with risk premiums which constitute different allowances that act as a payment for risk [4].

Classification of risks is a critical task, because the more professionally project manager could identify, estimate and classify different types of risks, the more effectively he could manage them. The complexity of building of classification of investment and construction risks is that there are lots of them and they are very diverse.

\section{Materials and methods}

General classification of investment risks is proposed. All risks are divided in external and internal ones to clarify on which an organization can influence, and on which does not:

1. Internal risk factors depending on the structure of the project, its riskiness, novelty, source of financing, marketing strategy, etc.;

2. External risk factors that do not depend on the progress of project implementation are the economic and political risks, rate of inflation, rate of return of other investments (bank deposits, investments into securities), yield rates (risk-free, industrial, average market), etc.

Influence on choice of the rate of both internal and external factors, in other words risks, is understandable: the greater the risk of project, the greater should be the return on it to attract the investor. The rate of return should not be less than yield on alternative sources, for example, on interest rates of deposit investment or interest rates on the securities market $[5,6,7]$.

General classification of investment and construction risks with dividing on internal and external factors that need to be addressed when calculating the discount rate is presented in the Table 1.

Table 1. General classification of investment and construction risks.

\begin{tabular}{|c|c|l|}
\hline Environment & Type of risk & \multicolumn{1}{c|}{ Risk factor } \\
\hline \multirow{7}{*}{$\begin{array}{c}\text { Internal } \\
\text { environment }\end{array}$} & Production & $\begin{array}{l}\text { - Loss or damage of fixed or working capital; } \\
\text { - Failure of energy and water supply systems; } \\
\text { - Low quality of materials, details, structures, equipment, } \\
\text { that don't allow using it for their intended purpose, etc. }\end{array}$ \\
\cline { 2 - 4 } & Technological & $\begin{array}{l}\text { - Non-compliance of technological process; } \\
\text { - Emergence of unforeseen work to address the defective } \\
\text { construction and installation works, etc. }\end{array}$ \\
\cline { 2 - 4 } & Social & $\begin{array}{l}\text { - Insufficient qualification of workers; } \\
\text { - Staff turnover and difficulties with the recruitment of } \\
\text { skilled workforce, etc. }\end{array}$ \\
\cline { 2 - 4 } & Innovative & $\begin{array}{l}\text { - Use of new equipment and technology; } \\
\text { - Probability of losses, due to absence of demand of } \\
\text { innovative product on the market; } \\
\text { - Impossibility to implement technological and engineering } \\
\text { solutions of investment and construction projects, etc. }\end{array}$ \\
\cline { 2 - 4 } & Organizational & $\begin{array}{l}\text { - Lack of timeliness to receive the license and patent rights; } \\
\text { - Disadvantages of design and survey works; }\end{array}$ \\
\cline { 2 - 4 } & \multicolumn{2}{|l}{}
\end{tabular}




\begin{tabular}{|c|c|c|}
\hline & & $\begin{array}{l}\text { - Disruption in the supply of necessary production } \\
\text { resources and components, etc. }\end{array}$ \\
\hline & Marketing & $\begin{array}{l}\text { - Low-quality assessment of market conditions; } \\
\text { - Disadvantages in the marketing strategy, etc. }\end{array}$ \\
\hline & Specific & $\begin{array}{l}\text { - Change of leadership; } \\
\text { - The sudden displacement of material and labor forces to } \\
\text { another object, etc. }\end{array}$ \\
\hline & $\begin{array}{c}\text { Risk of } \\
\text { unreliability of } \\
\text { participants }\end{array}$ & $\begin{array}{l}\text { - Misappropriation of funds; } \\
\text { - Dishonesty, insolvency, legal incapacity of the other } \\
\text { project participants; } \\
\text { - Violation of contract terms or contract termination; }\end{array}$ \\
\hline \multirow{7}{*}{$\begin{array}{c}\text { External } \\
\text { environment }\end{array}$} & Political & $\begin{array}{l}\text { - Political instability in the country; } \\
\text { - Threat of strikes; } \\
\text { - Insufficient for the retention of staff salary level, etc. }\end{array}$ \\
\hline & Macroeconomic & $\begin{array}{l}\text { - Increase of the inflation rate; } \\
\text { - Change in tax rates; } \\
\text { - The devaluation of the ruble, etc. }\end{array}$ \\
\hline & Legal & $\begin{array}{l}\text { - Incompleteness of the legal framework; } \\
\text { - Modification of existing or adoption of new legal acts; } \\
\text { - Level of protection of the domestic market, etc. }\end{array}$ \\
\hline & Industrial & $\begin{array}{l}\text { - Violation of interaction with related industries (for } \\
\text { example, municipal facility); } \\
\text { - Instability of the industry, etc. }\end{array}$ \\
\hline & Market & $\begin{array}{l}\text { - Changes in consumer requirements; } \\
\text { - Increasing competition. }\end{array}$ \\
\hline & Financial & $\begin{array}{l}\text { - Changing of the interest rate (cost of debt capital); } \\
\text { - Change in the coefficients of systemic risk, risk-free and } \\
\text { average market rate. }\end{array}$ \\
\hline & $\begin{array}{l}\text { Climatic and } \\
\text { environmental }\end{array}$ & $\begin{array}{l}\text { - The emergence of natural disasters; } \\
\text { - The emergence of man-made disasters; } \\
\text { - The emergence of social and domestic disasters. }\end{array}$ \\
\hline
\end{tabular}

Of course, the risks and risk-contributing factors which were listed in Table 1 don't show all their diversity, because generally accepted and universal classification of risks doesn't exist today, and they are different in each specific situation. That's why the goal of each investment and construction project should be a qualitative assessment of the risks that affect the accepted discount rate [8].

Combination of risks and risk-contributing factors is individual for each investment and construction project. Therefore, in each specific case assessors form individual set of them and assess the possibility of their occurrence, level of influence on achieving the goals of investment and construction project and project sustainability to the specific risk factor. To form an individual set of risk-contributing factors, it's invited to consider the factor space (Fig.1) suitable for filling in each individual case. On the basis of this factor space, the set of significant factors for the project is formed and assessed. Scaling, i.e. change in the size, of the suggested factor space depends on the number of experts, their experience, knowledge, as well as on base of required data and its availability, representativeness, reliability $[9,10]$. 


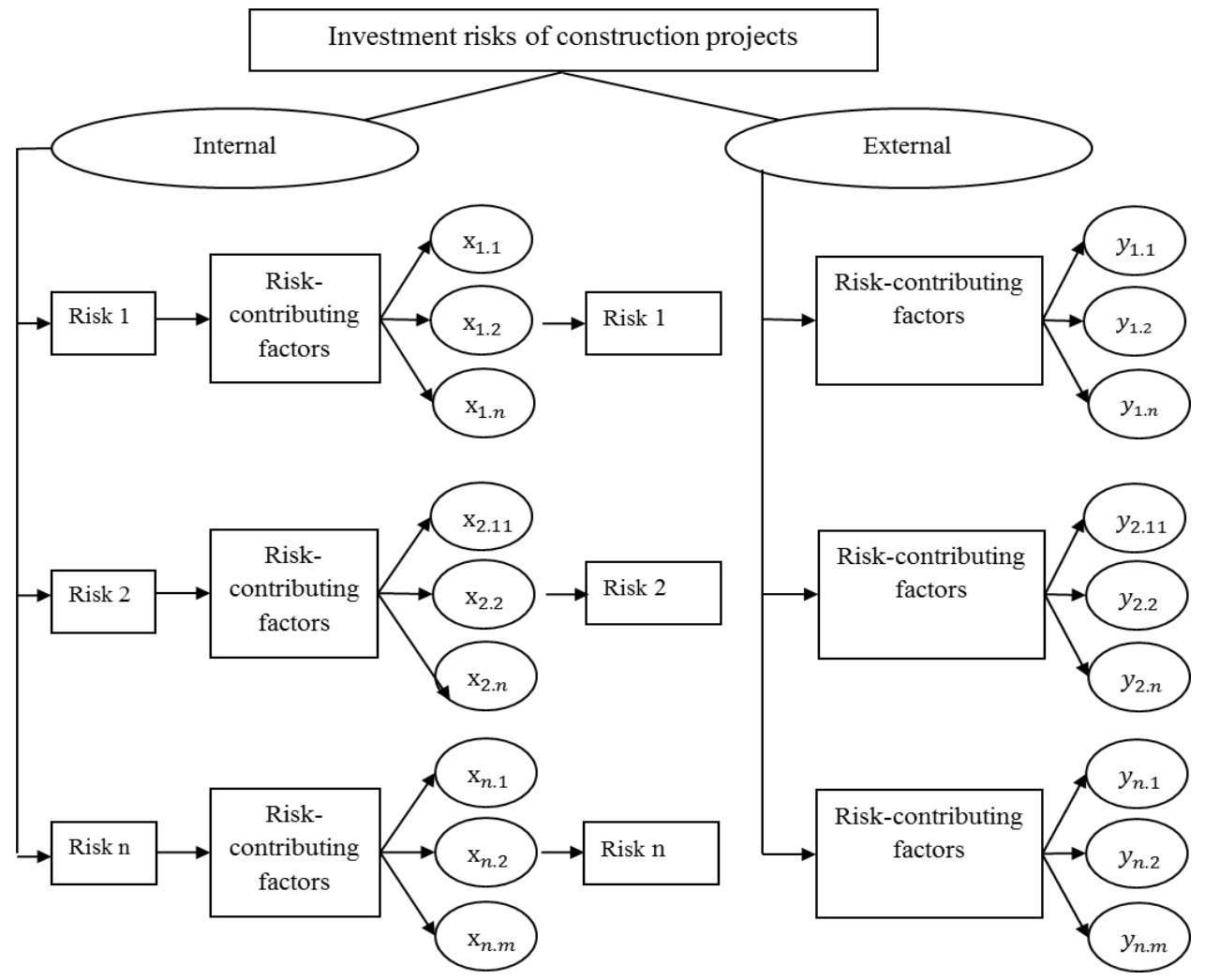

Fig. 1. Risk-contributing factor space.

\section{Results}

The analysis of risks and risk-contributing factors is largely depends on initial data of investment and construction project. On its basis collection of necessary information for assessing its risk begins. General algorithm for assessment of risk in investment and construction project is presented on Fig. 2

The result of assessment of risk factors affecting on investment and construction project is the quantitative indicator of the risk, or in other words, "risk premiums".

Thus, the assessment of investment and construction project requires a careful analysis of external and internal influencing factors. Some of them could and should be managed. When assessing risks, it should be taken into account that as an economic category, risk is an event which might happen or not. Managing the risk, i.e. taking various measures that, in certain extent, allow predicting the occurrence of risk event, it is possible to reduce the level of risk [11]. 


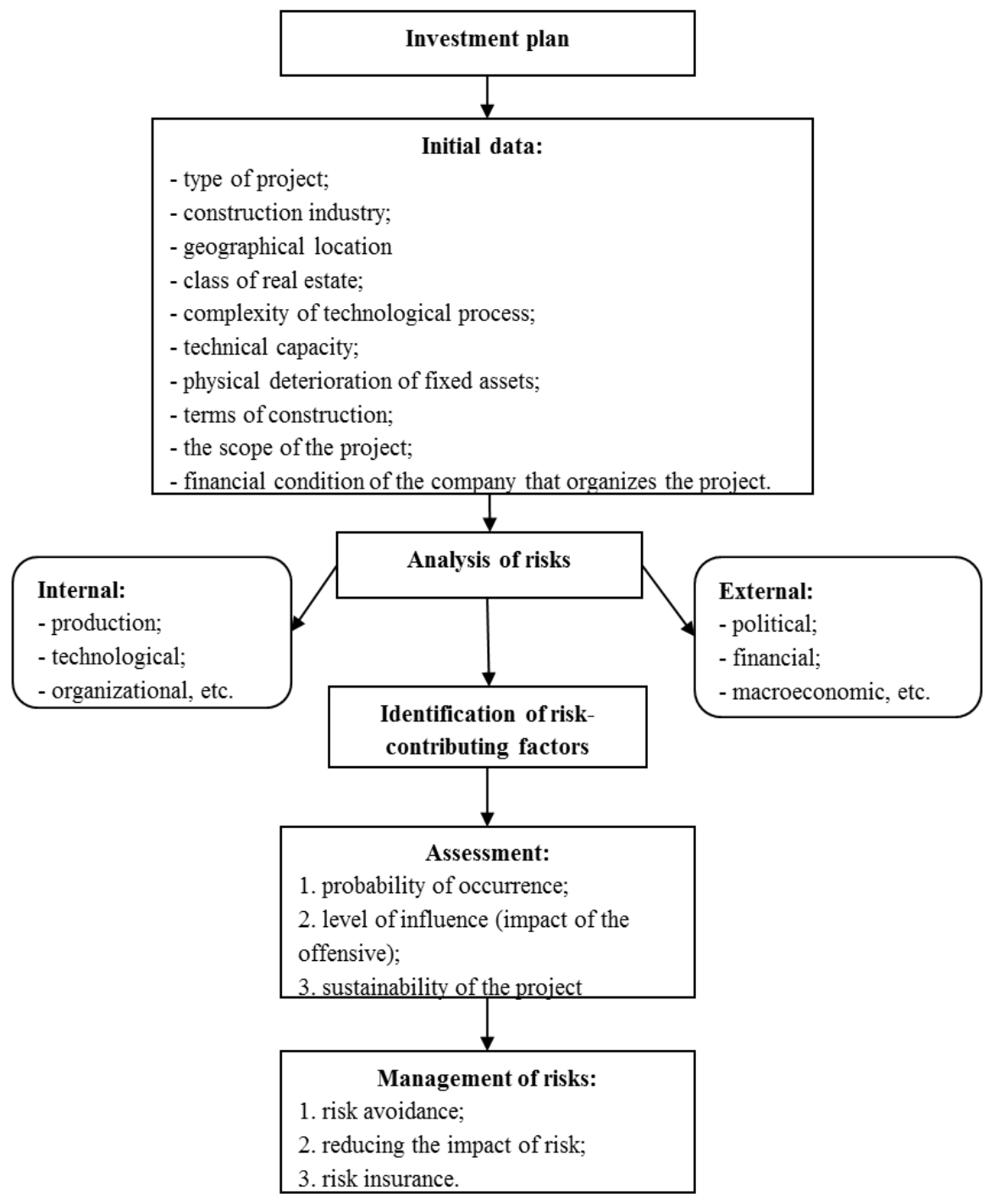

Fig. 2. General algorithm for assessment of risk in investment and construction project.

\section{Discussions}

Risk management allows changing the discount rate, thereby changing the results of assessment of investment and construction project. Risk management is carried out on two stages of project's life cycle: planning and implementation. In the practice of project management the basic ways to reduce or avoid the risk are:

- sharing of risk between participants of the project;

- insurance;

- reservation of funds to cover unforeseen expenses;

- neutralization of private risks;

- reduction of risks in the financing plan 


\section{Conclusions}

Significantly, that in addition to possibility of risk management there is a tendency to change the level of risk during the project's life cycle. So, at the time of investment plan the risks are maximal, because investment is being made in a property that doesn't yet exist. After the completion of construction the risks are minimal, because the project passed the most dangerous stages: construction and commissioning. On this basis it is proposed to consider the relations between project's life cycle and the level of risk associated with its implementation.

\section{References}

1. V. Pukhkal, V. Murgul, M. Garifullin, Procedia Engineering 117, 624-627 (2015)

2. R.S. Golov, V.V. Shilov, S.A. Silantiev, Training the specialists of combined engineering and economic profile at Russian universities: cluster approach ASEE International Forum, 20766 (2017)

3. V. Kankhva, Procedia Engineering 165, 1300-1304 (2016) doi: 10.1016/j.proeng.2016.11.855

4. A. Jones, G. Fallon, R. Golov, European Business Review 12(4), 187-197, doi: 10.1108/09555340010336871

5. A. Bril, O. Kalinina, O. Valebnikova, Lecture Notes in Computer Science 9870, 766775 (2016) doi: 10.1007/978-3-319-46301-8_67

6. A.K. Orlov, I.Y. Chubarkina, MATEC Web of Conferences 08015, 106 (2017)

7. I.V. Ilin, A. Lepekhin, A.I. Levina, O.Yu. Iliashenko, Advances in Intelligent Systems and Computing 692, 1306-1314 (2018) doi:10.1007/978-3-319-70987-1_138

8. E. Nezhnikova, IOP Conf. Series: Earth and Environmental Science 90, 012162 (2017) doi :10.1088/1755-1315/90/1/012162

9. E. Kiseleva, M. Nekrasova, M. Mayorova, M. Rudenko, V. Kankhva, International Review of Management and Marketing 6, 95 (2016)

10. I. Lukmanova, M. Mishlanova, International Journal of Economics and Financial Issues 5, 208-216 (2012)

11. V. Gasilov, N. Anisimova, N. Provotorov, MATEC Web of Conferences 106, 08035 (2017) DOI: 10.1051/ mateconf / 201710608035 